\title{
Evaluation of the best time for spawning of Pleurotus eryngii mushroom to standardize the cultivation technology in Rajasthan, India
}

\section{Akansha Deora ( $\square$ akanshadeora22@gmail.com )}

Maharana Pratap University of Agriculture and Technology

\section{Dr. S.S. Sharma}

Maharana Pratap University of Agriculture and Technology

Abhitej Singh Shekhawat

Maharana Pratap University of Agriculture and Technology

\section{Suresh Kumar}

Maharana Pratap University of Agriculture and Technology

\section{Poonam Kumari}

Maharana Pratap University of Agriculture and Technology

\section{Kalpana Yadav}

Maharana Pratap University of Agriculture and Technology

\section{Vinita Dahima}

Maharana Pratap University of Agriculture and Technology

\section{Poonam Yadav}

Maharana Pratap University of Agriculture and Technology

\section{Research Article}

Keywords: Biological efficiency, king oyster mushroom, mycelial run, pinhead initiation, spawning

Posted Date: February 4th, 2022

DOI: https://doi.org/10.21203/rs.3.rs-1301199/v1

License: (1) (1) This work is licensed under a Creative Commons Attribution 4.0 International License. Read Full License 


\section{Abstract}

The aim behind this experiment was to know the suitability of months that gives better Biological efficiency and its sustainability with respect to yield. This research work was accomplished at the project of AICRP on medicinal mushroom unit in Department of Plant Pathology, Rajasthan College of Agriculture, Udaipur during the months of November to April in the natural climatic conditions, where the temperature and the relative humidity of cropping room ranged between $9-24^{\circ} \mathrm{C}$ and $60-80 \%$, respectively. This work tells you about the best time for spawning to standardize the cultivation technology of Pleurotus eryngii in Zone IV a (Udaipur region) as well as in Rajasthan. Out of four different months (November, December, January and February) tested for spawning, the fastest mycelial run and pinhead initiation occurred in December and January months whereas, maximum B.E.\% was observed in the month of December followed by November. Hence, it clearly indicates that the best suited time for cultivating King Oyster (Pleurotus eryngii) Mushroom is during winter months of the year.

\section{Background}

The word "Mushroom" has been used in different forms at different times and in different nations. Commonly, mushroom refers to all macrofungi which possess stalks and caps or all the large and fleshy fungi [1]. They are rich in protein, dietary fibre, vitamins and minerals [2-4]. In India, due to suitable weather conditions and abundance of cheaper agro residues like straw, leaves and stalks of different field crops, mushroom cultivation has been adopted by progressive farmers, which not only benefitted them with an additional source of income but they are also recycling the farm products.

Since water resources are not satisfactory in Rajasthan and agriculture is mostly rainfed that is why mushroom cultivation has great potential in Rajasthan as this industry is labour intensive \& requires less water and land as compared to commercial farming. Currently in Rajasthan, the subtropical and tropical varieties of mushroom like oyster and milky mushroom are rising and gaining popularity. Button mushroom is also being grown but due to unavailability of temperate climate throughout the year, it is being grown during very limited period of the year i.e. winter season only [5].

Oyster mushroom is classified under Phylum - Basidiomycota and belongs to Family - Pleurotaceae. Pleurotus eryngii (DC.ex FR.) Quel. is the largest species in the Oyster mushroom genus, Pleurotus, which also contains $P$. ostreatus, $P$. sajor-caju and $P$. florida. It has a thick, white and meaty stem or stalk called stipe, a large tan cap called pileus and gills are present underside of the pileus. $P$. eryngii is also called as Kabul Dhingri and King Oyster Mushroom [6, 7]. Unlike other mushrooms species, this genus shows much diversity in their adoption to the varying agro climatic conditions [8]. Different species of Pleurotus can be grown all around the year at various temperature ranges. In subtropical climatic conditions, some species of Pleurotus are suitable like $P$. citirinopileatus, $P$. sajor-caju, $P$. florida and $P$. salmoneo stramineus (Pink oyster) that commonly require comparatively low temperatures making them suitable to cultivate during September to March months of the year in the state. The suitability of $P$. eryngii is found to be in winter months of the year. However, not much work had been done to standardize its cultivation technology in 
existing weather conditions; the study is aimed to evaluate the optimum parameters for getting higher biological efficiency.

\section{Results}

Data in the Table 1 indicates that, among the different months tested for the efficacy of $P$. eryngii production, the mycelial run was observed to be the fastest in the month of December (19 days) and January (19.4 days). Months of November and February gave same results (22.4 days) and the same trend was followed for the pinhead initiation time. This trend (Fig. 1) exhibited due the fact that the temperature started declining slowly with the onset of November and reached minimum range at the end of November and continued to be in the same minimum range till mid January and further, started somewhat increasing at the end of January. So, the bags spawned on $1^{\text {st }}$ December and $1^{\text {st }}$ January gave significantly faster growth in comparison to the bags spawned on $1^{\text {st }}$ November and $1^{\text {st }}$ February. Whereas, the highest B.E. \% (76.7\%) and maximum number of fruit bodies (30.6) were obtained in the month of December (Table 2). November gave significantly higher BE\% $(72.1 \%)$ than January $(65.5 \%)$ and February (56.8\%). The fluctuation in this trend (Fig. 2) in case of BE\% is because of the higher temperature after mid January and lower temperature after mid November when the fruiting bodies of January and November months started developing, respectively. Average fruit body weight and fruit body measurements were highest in the months of January (93.5g) and February (93.1 g) as shown in Table 3, Fig. 3 and Fig. 4. The experiment was statistically significant. Being the temperate in nature, results shown by mushroom were accordingly perfect.

Table 1. Effect of spawning in different months on spawn run and pinhead initiation of Pleurotus eryngii.

Treatment Days taken in spawn run Days taken in Pin head initiation

\begin{tabular}{lll}
\hline November & 22.4 & 28.0 \\
\hline December & 19.0 & 25.0 \\
\hline January & 19.4 & 26.0 \\
\hline February & 22.4 & 28.0 \\
\hline SEm \pm & 0.3 & 0.4 \\
\hline $\mathrm{CD}(\mathrm{p}=0.05)$ & 0.9 & 1.1
\end{tabular}

SEm \pm : Standard error of the mean. CD $(p=0.05):$ Critical difference, where $p=$ level of significance. All the observations are average of five replications.

Table 2. Effect of spawning in different months on yield and BE\% of Pleurotus eryngii. 


\begin{tabular}{llll} 
Treatment & Number of fruiting bodies & Yield $(\mathbf{g})$ & Biological efficiency \% \\
\hline November & 17.0 & 720.8 & 72.1 \\
\hline December & 30.6 & 767.4 & 76.7 \\
\hline January & 8.2 & 655.2 & 65.5 \\
\hline February & 8.8 & 568.2 & 56.8 \\
\hline SEm \pm & 2.0 & 33.2 & 3.3 \\
\hline $\mathrm{CD}(\mathrm{p}=0.05)$ & 6.0 & 99.4 & 9.9
\end{tabular}

SEm \pm : Standard error of the mean. CD $(p=0.05)$ : Critical difference, where $p=$ level of significance. All the observations are average of five replications.

Table 3. Effect of spawning in different months on morphology of Pleurotus eryngii.

\begin{tabular}{|c|c|c|c|c|}
\hline \multirow[t]{2}{*}{ Treatment } & \multirow{2}{*}{$\begin{array}{l}\text { Average fruit body weight } \\
\text { (g) }\end{array}$} & \multicolumn{3}{|c|}{ Fruit Body Measurement } \\
\hline & & $\begin{array}{l}\text { Pileus } \\
\text { (cm) }\end{array}$ & Stipe length (cm) & Stipe diameter (cm) \\
\hline November & 45.1 & 7.9 & 5.0 & 3.0 \\
\hline December & 26.3 & 6.5 & 4.6 & 2.0 \\
\hline January & 93.5 & 10.0 & 5.7 & 4.5 \\
\hline February & 93.1 & 9.0 & 5.5 & 4.0 \\
\hline SEm \pm & 16.3 & 0.1 & 0.1 & 0.1 \\
\hline$C D(p=0.05)$ & 48.8 & 0.4 & 0.4 & 0.3 \\
\hline
\end{tabular}

SEm \pm : Standard error of the mean. $\operatorname{CD}(p=0.05)$ : Critical difference, where $p=$ level of significance. All the observations are average of five replications.

\section{Discussion}

Pleurotus mushroom is gaining popularity among the growers due to its simple cultivation technology of growing on wheat or paddy straw over other agro residues. Its cultivation helps in recycling of agrowastes as well as fills the protein gap prevalent among majority of the country. According to this worldwide survey, various types of wastes have been found to be useful for Oyster Mushroom growing in particular months. Around $20^{\circ} \mathrm{C}$ and $20 \pm 1^{\circ} \mathrm{C}$, respectively are most appropriate temperatures for cultivating Pleurotus eryngii $[9,5]$. A minimum temperature of $\left(13.4-24.2^{\circ} \mathrm{C}\right)$ proved to be the best for growing oyster mushroom [10]. Winter season was found to be promising for obtaining 
maximum yields and B.E.s of different strains of Pleurotus species [11]. This confirms our findings that the mycelial run and pin head initiation in our case was fastest in the month of December (19 days) and January (19.4 days), when the average temperature mean of maximum and minimum remains well under

$20 \pm 1^{\circ} \mathrm{C}$ as per meteorological data. Whereas, the highest B.E. \% (76.7\%) and maximum number of fruiting bodies (30.6) were obtained in the month of December.

\section{Conclusion}

According to the results of our study, it clearly indicates that the best suited time for cultivating King Oyster (Pleurotus eryngii) Mushroom is during winter months of the year starting from October to February and if temperature remains suitable, it can be up to March also.

\section{Methods}

The experiment was performed in accordance with relevant guidelines and regulations.

Mother Culture. Pure cultures were procured from Directorate of Mushroom Research, Chambaghat, Solan, Mushroom Research and Training Centre, Haryana Agricultural University, Murthal, Haryana and Mushroom Research Laboratory, Indian Institute of Horticultural Research, Hesarghatta, Bengluru. Cultures were multiplied on malt extract agar and maintained in test tubes. We prepared six combinations from these three cultures through mycelial anastomosis. Out of them, one strain was found to be the most suitable under sub-tropical climate, which we later named as "Pratap King Oyster-1" (P.K.O-1) and this strain has been used in our experiment.

Preparation of master culture. The study complies with local and national regulations. For the collection of seeds or plants, all relevant permissions or licenses have been obtained. Healthy wheat grains were soaked in water overnight and were boiled up to semi cooked conditions in the next morning. Excess water was drained off and seeds were left for surface drying. These seeds were then mixed with $1 \%$ $\mathrm{CaCO}_{3}$ and were filled in milk glass bottles or polypropylene bags which we later sterilized at $20 \mathrm{lbs}$ psi pressure $\left(126.5^{\circ} \mathrm{C}\right)$ for $2 \mathrm{hrs}$. After cooling, each bag was inoculated aseptically with two mycelial agar bits of P.K.O.-1 culture in Laminar Air Flow and incubated at $20 \pm 1^{\circ} \mathrm{C}$ in incubator for $20-25$ days till the grains were fully impregnated with the mycelium of inoculated mushroom culture [6] (Fig. 5).

Preparation of substrate. The experiment was laid out by using straw of wheat crop, since; it is easily available and cheap. Straw was chopped into $3-5 \mathrm{~cm}$ pieces and chemically treated by soaking in mixture of Bavistin $(8 \mathrm{~g})$, Formalin $(300 \mathrm{ml})$ and Nuvan $(30 \mathrm{ml})$ with water in drum of 200 litre capacity and kept overnight. On the next day, after decanting excess water, it was used for spawning purpose [12] (Fig. 6).

Spawning. The experiment was performed for the four winter months viz. November, December, January and February. For layer spawning, substrate filled in bag was pressed to a depth of 2-3 inches and broadcasted with spawn above it. Similarly, 2nd and 3rd layers of entire substrate were put simultaneously and after spawning, some amount of substrate is put over it, and then the bags tied up 
with rubber bands (Fig. 7). Thus, five bags in each month were spawned and they were maintained under optimum conditions of mushroom growth. The date of spawning was also kept same in every month. Thus, four treatments with five replications of each were placed using Completely Randomized Design to reach the conclusion so that a consolidated recommendation can be made as to how the King Oyster can be grown with maximum $B E$.

Crop management and harvesting. After 20-22 days of spawning, when spawn run gets completed and bags turns white in colour due to white mycelial run, the polythene covers were teared off. Pin heads came out after 2 to 3 days of removing the polycovers which later developed into mature fruit bodies [13]. At this stage, mushrooms were plucked off by twisting in clockwise direction at the substrate level, counted and weighed separately for each replication at every harvest (Fig. 8). Yield was recorded and the Biological efficiency was also calculated.

Biological efficiency. The Biological efficiency was also calculated by following the given formula [1].

\section{B.E. $\%=\frac{\text { Weight of fresh fruiting bodies }(\mathrm{g})}{\text { Dry weight of substrate }(\mathrm{g})} \times 100$}

Statistical analysis. Statistical Analysis Software (SAS software) developed by Indian Statistical Research Institute (ISRI), New Delhi was used for performing statistical analyses of data. The critical differences among treatment groups were determined using the ANOVA test at level of significance $(p=$ 0.05). All the experiments were carried out in five replications in Completely Randomized Design (CRD).

The data analysis for this paper was generated using SAS software. Copyright [2014] SAS Institute Inc. SAS and all other SAS Institute Inc. product or service names are registered trademarks or trademarks of SAS Institute Inc., Cary, NC, USA.

\section{Declarations}

Data availability. Requests for data and materials should be addressed to S.S.S (email: sharmass112@gmail.com)

\section{Authors' contributions}

S.S.S. designed the study and guided throughout all the experiments. A.D. collected the materials and conducted experimental methods with the help of A.S.S., P.K., K.Y., V.D., S.K. and P.Y. A.D. wrote the manuscript and S.S.S. read and revised it, and all the authors approved the final version of manuscript.

\section{Acknowledgements}

I acknowledge the help rendered for this study by Rashtriya Krishi Vikas Yojna (RKVY) Project funded by Government of Rajasthan and Director Research, Maharana Pratap University of Agriculture and Technology, Udaipur, India. 
Competing Interests: The authors declare no competing interests.

Disclaimer- All photographs are original and copy right of the author (A.D.).

\section{Additional information}

Correspondence and requests for materials should be addressed to A.D.

\section{References}

1. Chang, S. T. \& Miles, P. G. Mushroom biology- a new discipline. Myco. 6, 64-65 (1992).

2. Alam, N., Amin, R., Khan, A., Ara, I., Shim, M. J., Lee, M. W. \& Lee, T. S. Nutritional analysis of cultivated mushrooms in Bangladesh- Pleurotus ostreatus, Pleurotus sajoraju, Pleurotus florida and Calocybe indica. Mycobiol. 36, 228-232 (2008).

3. Sabaratnam, V., Kah-hui, W, Naidu, M. \& David P. R. Neuronal health-Can culinary and medicinal mushrooms help. J. Tradit. Complement. Med.3, 62-68 (2011).

4. Singh, R. A review on different benefits of mushroom. IOSR-JPBS. 12, 107-111 (2017).

5. Kumar, A. Investigation on cultivation of Pleurotus eryngii (Kabul Dhingri) in Rajasthan. M.Sc. Thesis submitted to MPUAT, Udaipur, Rajasthan. (2005).

6. Moonmoon, M. M., Uddin, N., Ahmed, S., Shelly, N. J. \& Khan, M. A. Cultivation of different strains of king oyster mushroom (Pleurotus eryngii) on saw dust and rice straw in Bangladesh. Saudi J. of Bio. Sci. 17, 341-345 (2010).

7. Ryu, J., Kim, M. K., Im, C. H. \& Shin, P. Development of cultivation media for extending the shelf life and improving yield of King Oyster mushrooms (Pleurotus eryngii). Sci. Hortic.193, 121-126 (2015).

8. Zadrazil, F. and H. C., Dube. The oyster mushroom importance and prospects. Mushroom Res. 1(1), 25-32 (1992).

9. Theochari, I., Nikolaou, A., Poulou, A., Paroussi, G., Voyiatzis, D, and Paroussis, E. Resources of Pleurotus ostreatus and Pleurotus eryngii in Greece; Perspectives for cultivation and mushroom production. Proceeding of the second Balkan symposium on vegetables and potatoes. Greece. Acta Hortic. 579, 59-63 (2002).

10. Kumar, R. S. and Sarathi, V. Screening of Competitor Mould in Oyster Mushroom (Pleurotus florida), cultivation and their management. Int. J. Curr. Microbiol. Appl. Sci. 6, 264-270 (2017).

11. Saha, D. Studies on seasonal variation in yield and yield attributing characters of different strains of Pleurotus spp. M.Sc. Thesis submitted to IGAU, Raipur. (2017).

12. Peng, J. T. The cultivation of Pleurotus eryngii on rice straw substrate. J. Agric. Res. China. 45, 4, 382387: 7 (1996).

13. Kirbag, S. \&Akyuz, M. Effect of various agro-residues on growing periods, yield and biological efficiency of Pleurotus eryngii. J. Food, Agric. Environ. 6, 402-405 (2008). 
Figures

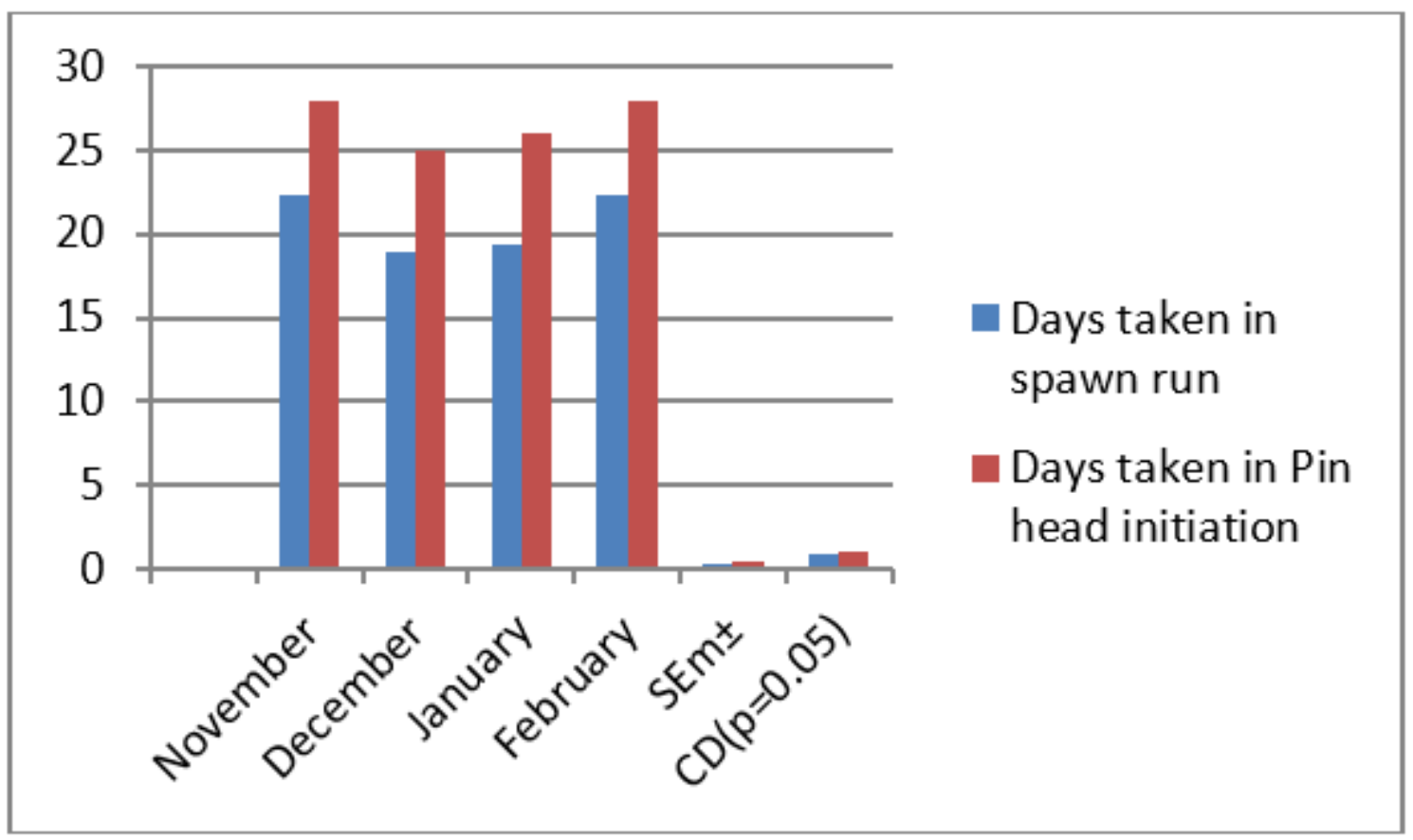

Figure 1

Average number of days taken in spawn run completion and pin head initiation in different months.

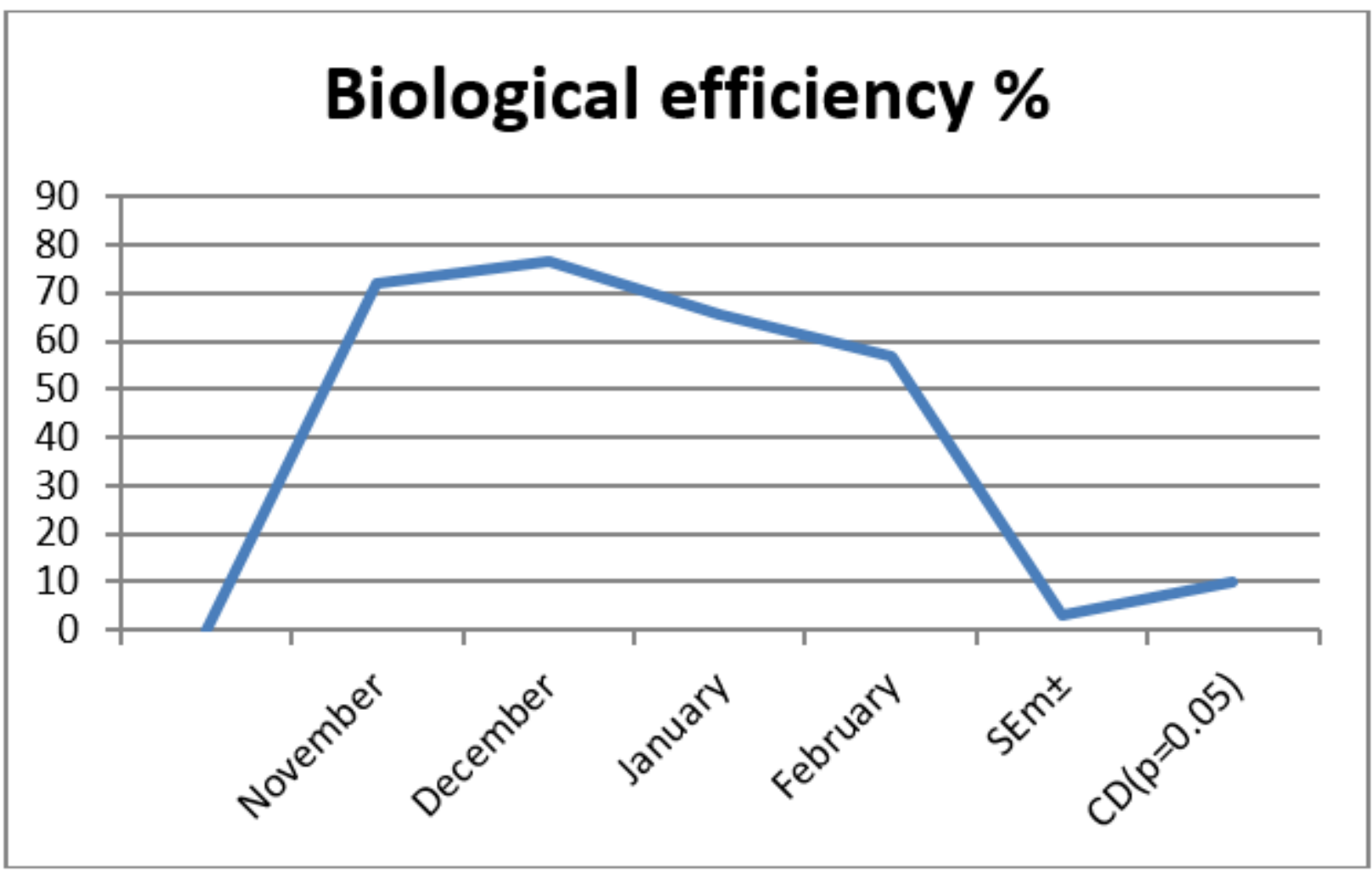

Figure 2 
$\mathrm{BE} \%$ obtained from different months.

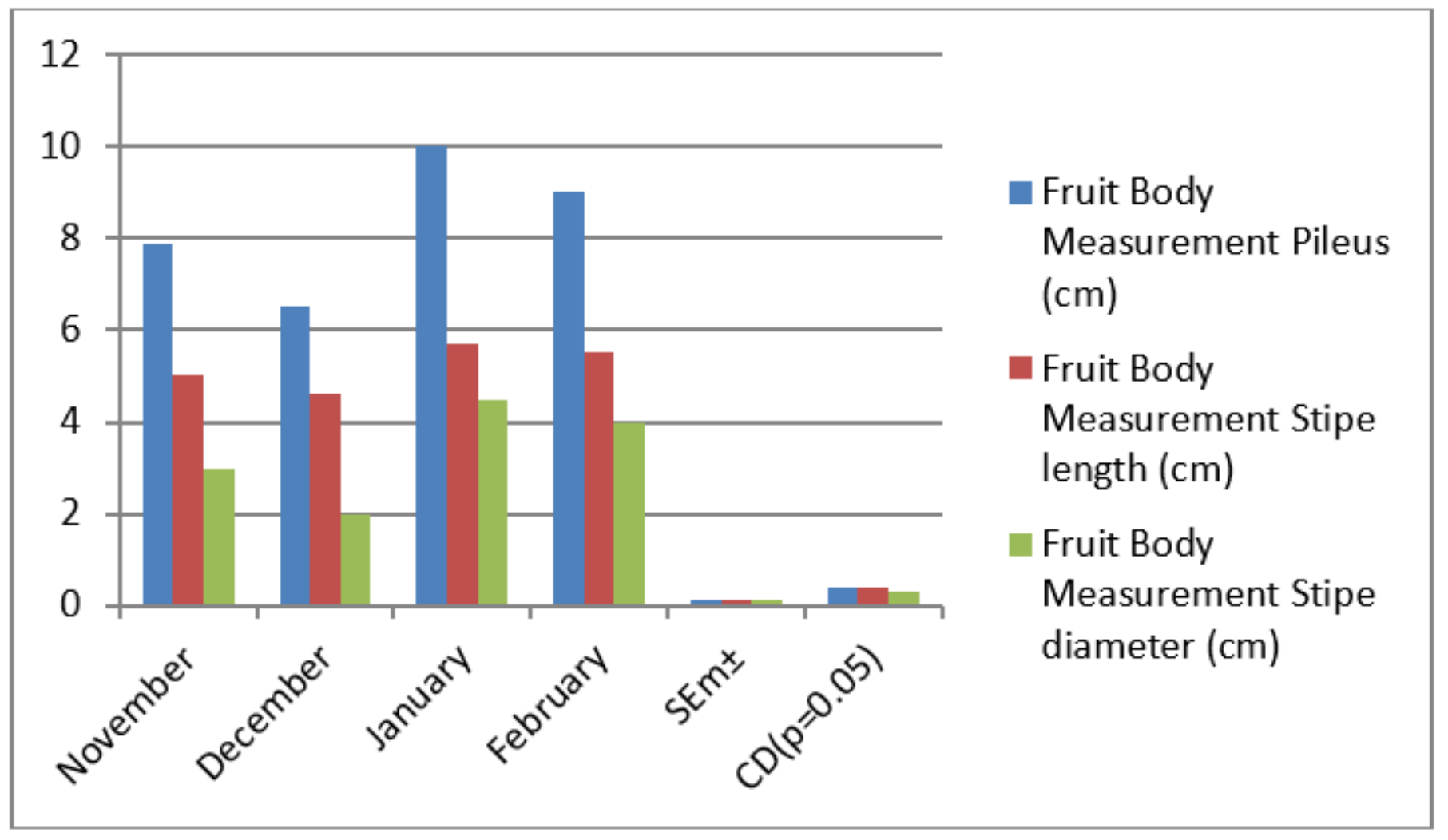

Figure 3

Effect of spawning in different months on morphology of Pleurotus eryngii.

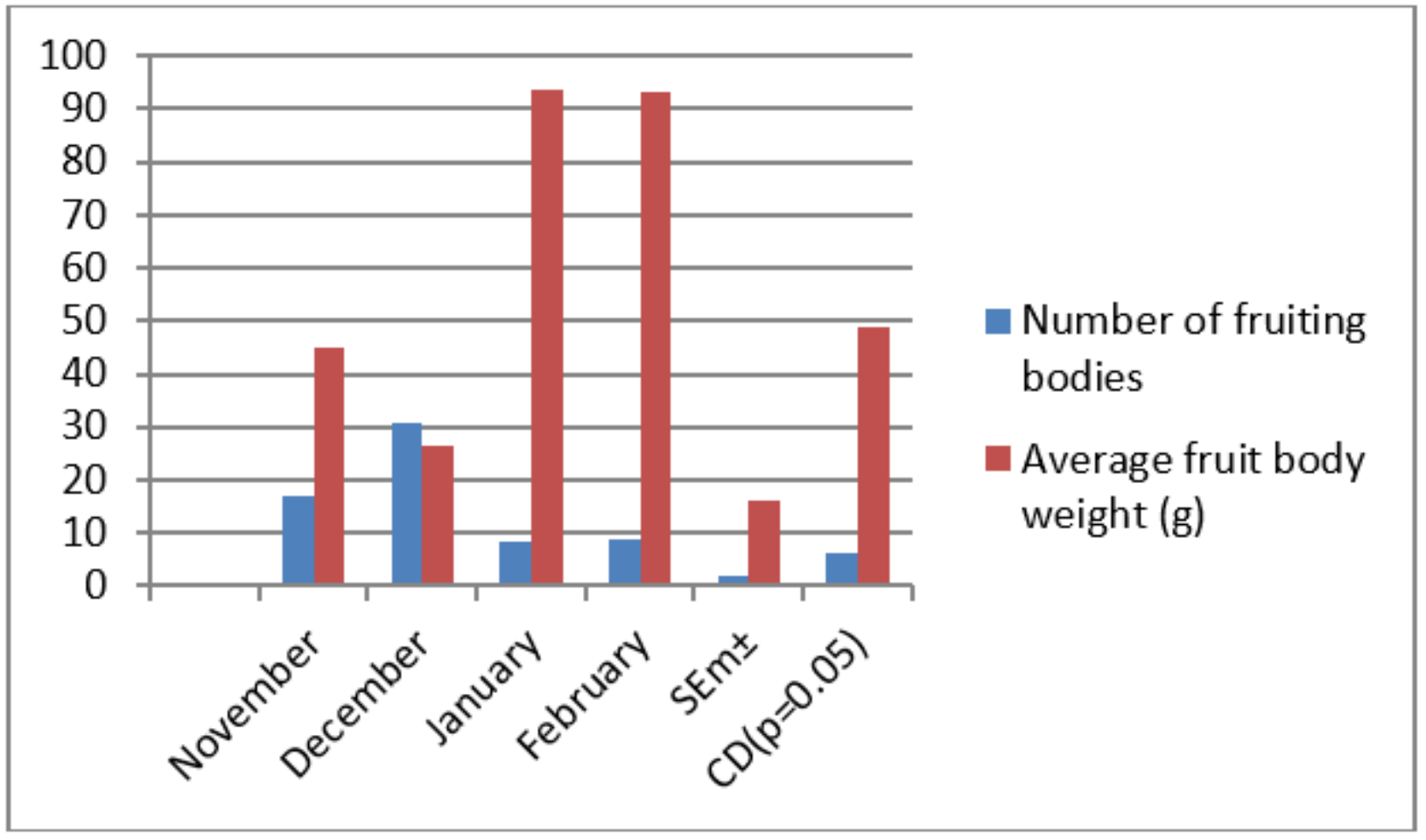


Figure 4

Number of fruiting bodies and average weight of Pleurotus eryngii in different months.

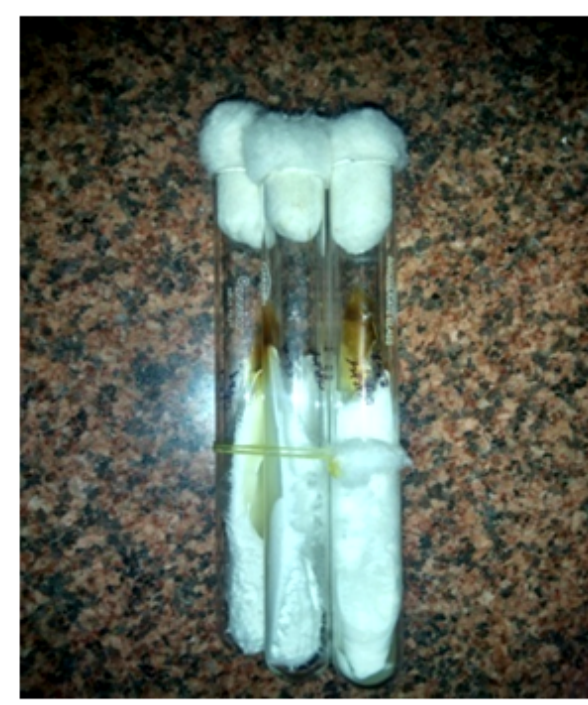

a. Mother Culture

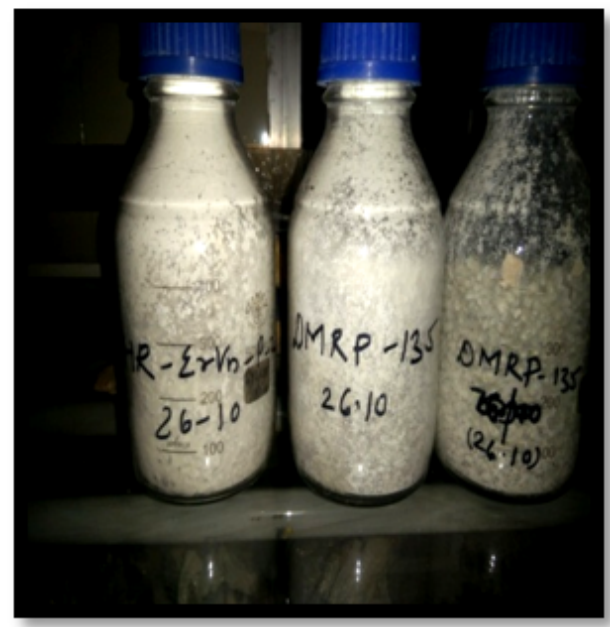

b. Preparation of Master Spawn

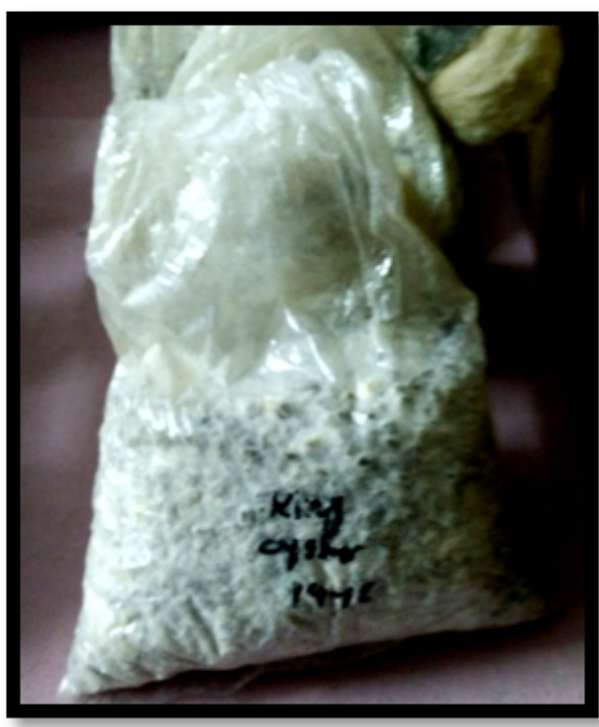

c. commercial spawn

\section{Figure 5}

Photographs of steps for spawn preparation of Pleurotus eryngii from culture.

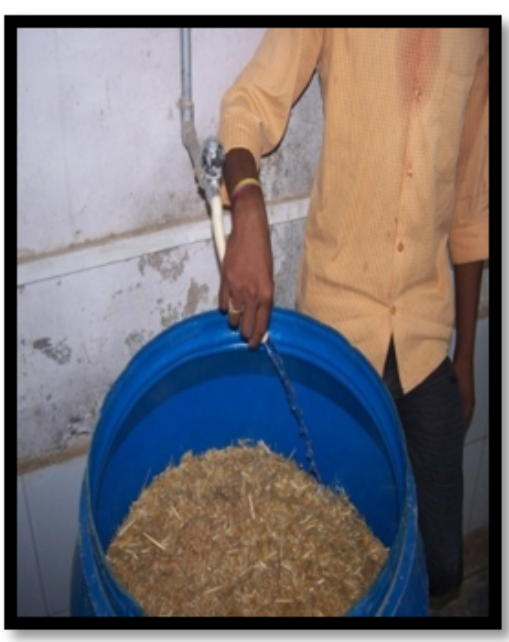

a. Soaking straw in water and giving chemical treatment

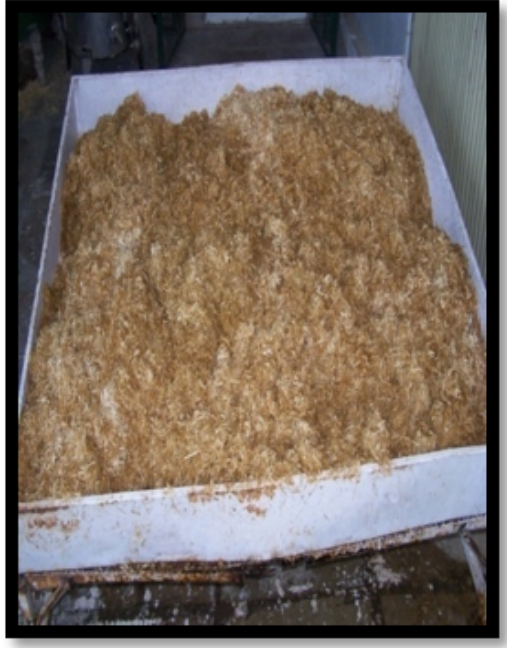

b. The treated straw left for decanting excess water (after $24 \mathrm{hrs}$ )

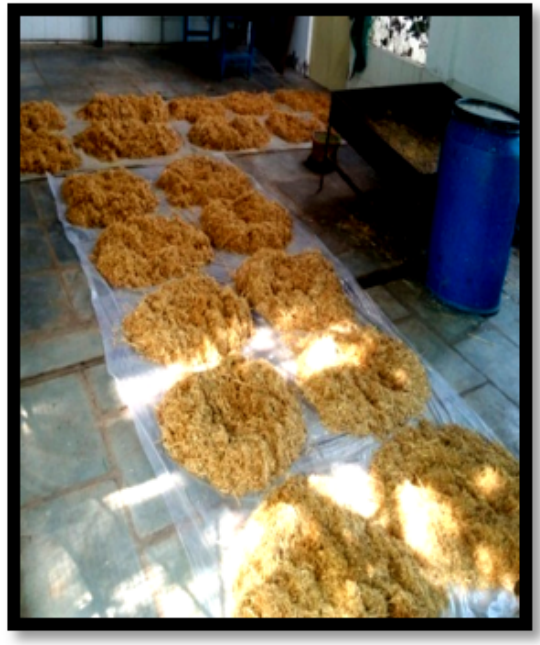

c. Air-drying till moisture remains $65 \%$

Figure 6 


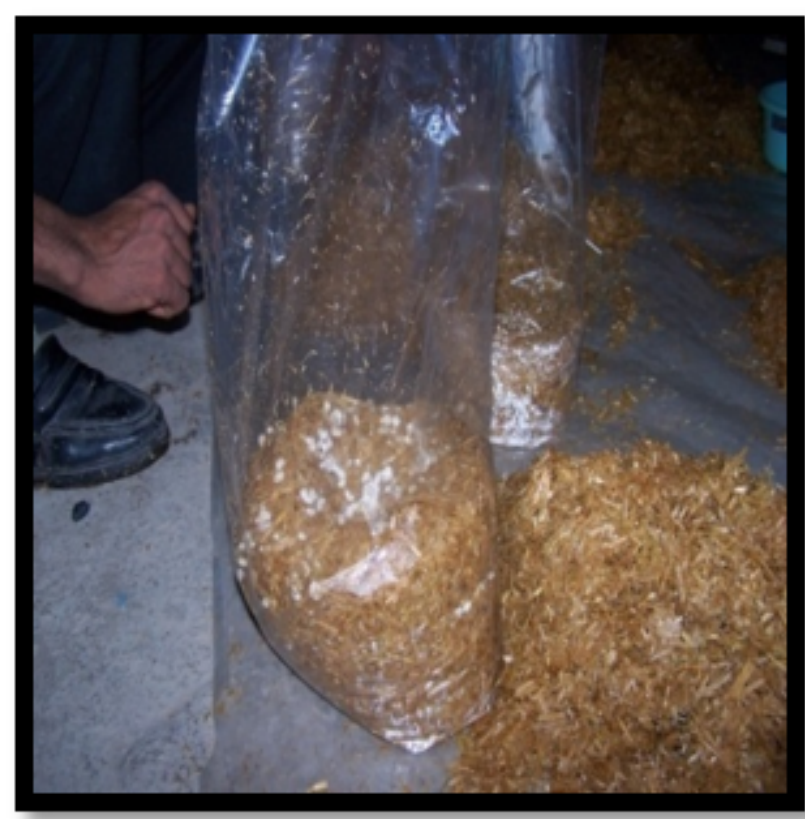

a. Layer Spawning in bags

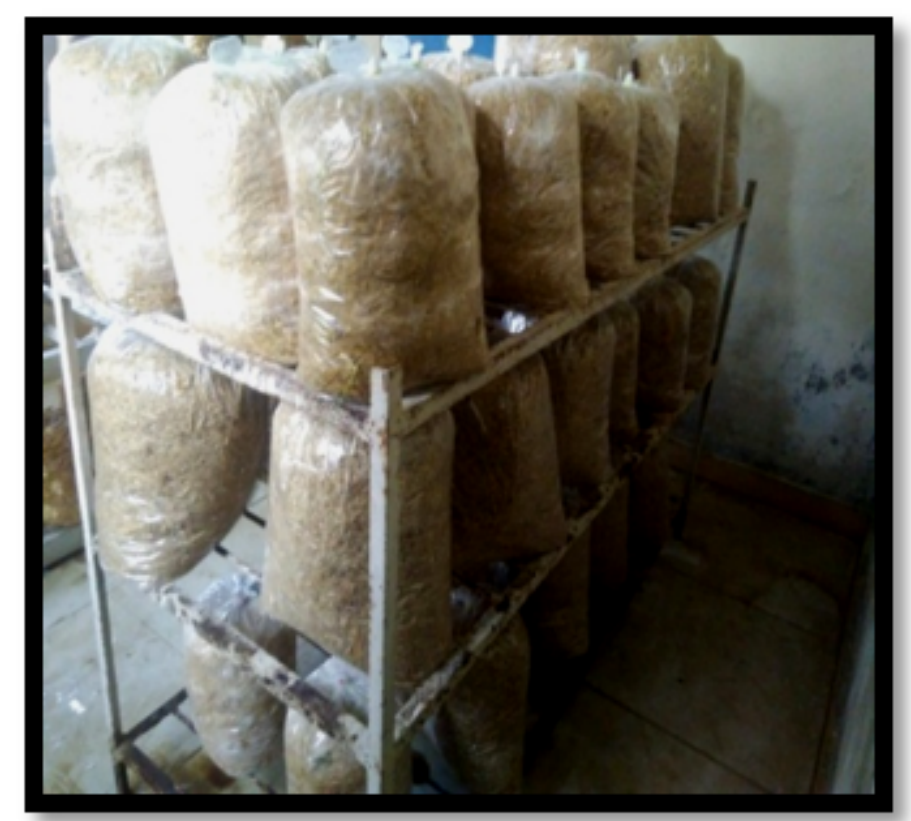

b. Spawn inoculated substrate placed in cropping room

Figure 7

Photographs of steps for substrate inoculation or spawning. 


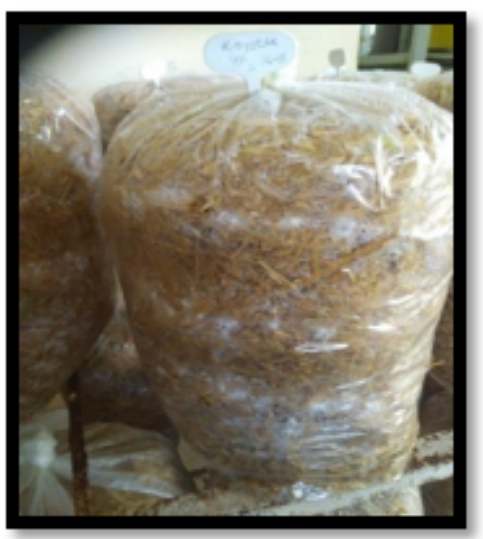

a. Spawn run initiation

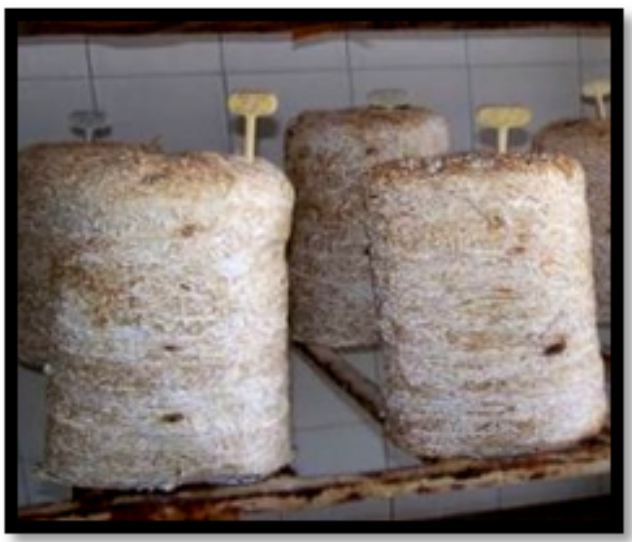

b. Spawn run completion and opening of the bags

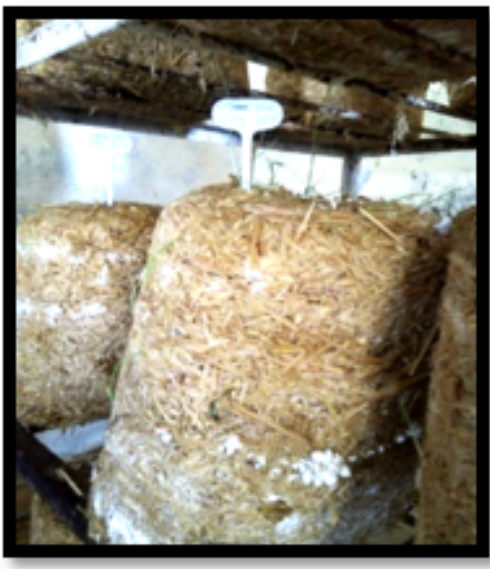

c. Pin-heads initiation

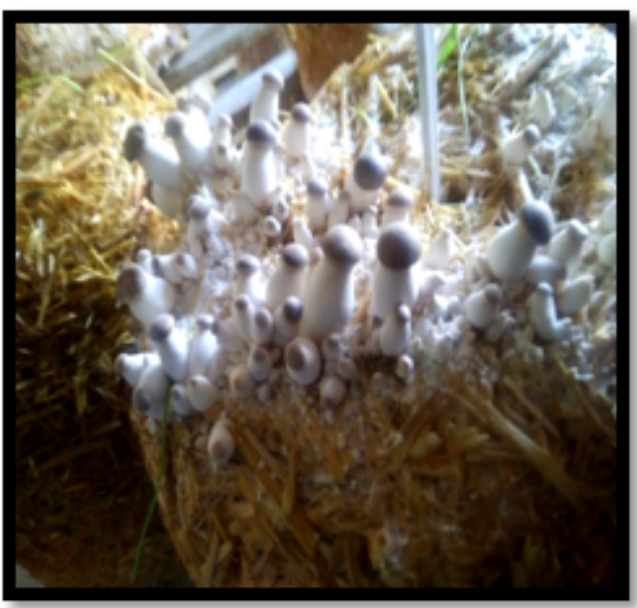

d. Young and developing fruiting bodies

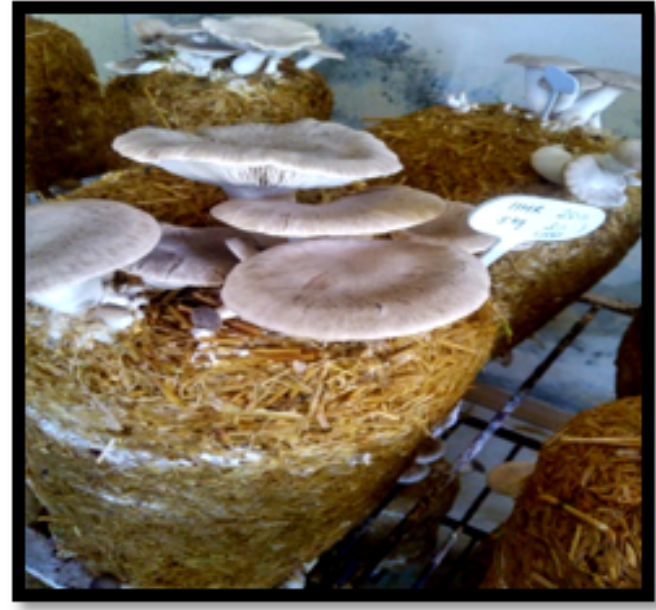

e. Mature fruit bodies

Figure 8

Photographs of different growth stages of Pleurotus eryngii from spawn run to harvesting. 